\title{
KEADILAN BAGI PENYALAHGUNA NARKOTIKA DI INDONESIA
}

\author{
${ }^{1}$ Rita Komalasari, ${ }^{2}$ Nurhayati, ${ }^{3}$ Cecep Mustafa \\ ${ }^{1}$ YARSI University, Menara Yarsi, \\ Jl. Letjen Suprapto No.Kav. 13, RT.10/RW.5, Jakarta Pusat \\ ${ }^{2}$ Prasetiya Mulya University, \\ J1. R.A. Kartini, RT.14/RW.6, Jakarta Selatan \\ ${ }^{3}$ University of Striling, \\ Stirling FK9 4LA, United Kingdom \\ Email: rita.komalasari2012@gmail.com,nurhayati.phd1@gmail.com, \\ cecepmustafa97@gmail.com
}

\begin{abstract}
This article presents the perceptions of Indonesian Judges in sentencing minor drug offenders. The judge holds a central role in the sentencing process, and because of the judicial discretion they can use it is essential to understand how judges come to their sentencing decisions. To develop an understanding of how judges perceive their actions in decision-making and sentencing of drug users, a total of 31 participants were interviewed. The data demonstrated that just ice is presented as conditional, depending on various influencing factors that are primarily, though not entirely, one of tension and contradiction. One of the factors that influence the judge's decision is politics and the legal apparatus. This article contributes to the perception of judges who are influenced by juridical and sociological factors.
\end{abstract}

Key words: conditional justice; influencing factors; the law; politics; the public;

\begin{abstract}
Abstrak
Artikel ini menyajikan persepsi para Hakim Indonesia dalam menjatuhkan hukuman terhadap pengguna narkotika. Hakim memegang peran sentral dalam proses hukuman, dan karena kebijaksanaan yudisial mereka dapat menggunakannya adalah penting untuk memahami bagaimana hakim sampai pada keputusan hukuman mereka. Untuk mengembangkan pemahaman tentang bagaimana hakim, memahami tindakan mereka dalam pengambilan keputusan kepada pengguna narkotika, sejumlah 31 peserta hakim diwawancarai. Data menunjukkan bahwa keadilan disajikan sebagai kondisional, tergantung pada berbagai faktor yang mempengaruhi yang terutama, meskipun tidak sepenuhnya, sebagai salah satu ketegangan dan kontradiksi. Faktor yang mempengaruhi putusan hakim salah satunya adalah politik dan aparat hukumnya. Artikel ini berkontribusi pada persepsi para hakim yang dipengaruhi oleh faktor yuridis dan faktor sosiologis.
\end{abstract}

Kata kunci: keadilan kondisional, faktor yang mempengaruhi, pengaruh politik dan publik 


\section{Latar Belakang}

Artikel ini menyajikan temuan-temuan yang menjawab pertanyaan penelitian pertama, "Faktor-faktor apa yang diungkapkan oleh para hakim yang memengaruhi mereka ketika menjatuhkan putusan kepada penyalahguna narkotika di peradilan Indonesia?" Dengan demikian, artikel ini mengkaji faktor-faktor penyebab utama yang menurut hakim mempengaruhi keputusan putusan mereka. Hutton (2006) berpendapat bahwa, untuk mengejar keadilan, seseorang perlu mengetahui faktor-faktor kunci apa yang berkontribusi terhadap putusan hakim. ${ }^{1}$ Tanpa mempertimbangkan faktor-faktor tidak langsung yang mempengaruhi putusan, maka belum tercapai keadilan. Oleh karena itu, perlu untuk memahami faktor-faktor yang berbeda yang dipertimbangkan ketika hakim menjatuhkan putusan. ${ }^{2}$

Studi tentang peradilan di seluruh yurisdiksi internasional perlu dipertimbangkan dalam konteks peneliti yang berasal dari Indonesia. Bagian penting dari konteks adalah dalam sifat budaya hukum di mana peradilan beroperasi. Cara peradilan beroperasi akan mempengaruhi pemahaman tentang penggunaan wewenang diskresi. Tujuan dari latar belakang ini adalah untuk menyajikan bentuk-bentuk keadilan dalam konteks budaya hukum tempat operasi. Di Dalam sejarah yurisprudensi barat, terdapat tiga bentuk keadilan tradisional menurut Duff dan Garland: hukum, moral, dan sosial. Bentuk keadilan tradisional pertama adalah keadilan hukum dimana hakim membuat pertimbangan sesuai dengan hukum. Dalam sifat budaya hukum di mana peradilan beroperasi, terdapat, setidaknya dua budaya hukum, yang pertama adalah adalah hukum common law, dan yang kedua adalah budaya hukum tertulis. ${ }^{3}$ Dalam budaya hukum tertulis, seperti di Indonesia, peradilan dianggap tidak memungkinkan untuk membuat kebijakan. Di Indonesia, peradilan dapat dianggap terikat oleh asas legalitas, yang mungkin menjadi kendala pembatasan dalam menerjemahkan hukum. Misalnya, tindak pidana terkait narkotika tercantum dalam Undang Undang. Oleh karena itu, peradilan mungkin perlu mengikuti aturan yang dikodifikasikan. Sebaliknya, dalam budaya hukum common law memungkinkan lebih banyak kesempatan untuk menyusun putusan mereka, tetapi sebagai akibatnya, peradilan mungkin perlu mengikuti pedoman putusan untuk menghindari perbedaan. Hal tersebut menunjukan bahwa, dalam budaya hukum common law, penerapan aturan hukum diimplementasikan melalui penerapan hukum dalam putusan mereka. ${ }^{4}$ Namun, perlu dicatat

1 Hutton, N. Sentencing as a social practice. In: S. Armstrong and L. McAra eds. Perspectives on punishment: the contours of control, (Oxford: Oxford University Press, 2006) p.155.

2 Ashworth, A. Responsibilities, rights and restorative justice. British Journal of Criminology, Vol. 3 (2002): 578.

3 Reimann, M., and Zimmermann, R, The Oxford handbook of comparative law, (Oxford University Press, 2019).

4 Hart, et al., The concept of law. $3^{\text {rd }}$. ed. (Oxford: Oxford University Press, 2012) 
bahwa dalam budaya hukum tertulis, seperti di Indonesia, terdapat juga perbedaan budaya mengenai pertimbangan yudisial tentang penerapan aturan hukum ketika menjatuhkan putusan kepada pengguna narkotika. Berdasarkan hal tersebut, pertimbangan hakim terkait penerapan aturan hukum pada saat menjatuhkan putusan kepada pengguna narkotika di Indonesia membutuhkan penyelidikan lebih lanjut.

Bentuk keadilan kedua adalah keadilan moral di mana hakim membuat penilaian berdasarkan moral. Pada tahun 2011, Duff mencatat bahwa keadilan yang didasarkan pada moralitas mungkin dipertanyakan. ${ }^{5}$ Namun, Duff menemukan sejumlah kecil studi yang berhubungan dengan masalah keadilan moral. Keyakinan moral para hakim dapat merujuk pada nilai agama yang tercermin terutama dalam Alkitab (untuk orang Kristen) atau dalam Al-Quran dan interpretasi para sarjana (untuk Muslim) atau prinsip moral tertulis yang secara eksplisit mendukung putusan mereka. Hart et al. (2012) berpendapat bahwa tanggung jawab moral hakim sering disebut ketika menjatuhkan putusan. Untuk menentukan seberapa pantas orang itu, Hart et al. (2012) menyatakan bahwa individu hakim akan melakukan penilaian mandiri di mana mereka mengikuti tanggung jawab moral mereka. ${ }^{6}$ Belas kasih dan empati dapat dianggap berakar pada gagasan yang berasal dari agama tentang tanggung jawab moral. Dalam beberapa yurisdiksi, seperti Skotlandia, dasar-dasar moral putusan secara eksplisit ditulis ke dalam pedoman putusan mereka. ${ }^{7}$ Namun, perlu dicatat bahwa di yurisdiksi lain seperti Indonesia, pemahaman Islam tentang aspek moral keadilan dapat memasuki pertimbangan hukum ketika dijatuhi putusan. Pemahaman Islam tentang unsur moral keadilan yang memasuki pertimbangan yudisial saat menjatuhkan putusan di Indonesia membutuhkan penyelidikan lebih lanjut.

Bentuk keadilan ketiga adalah keadilan sosial, yang memandang bahwa hakim harus mempertimbangkan manfaat yang akan dijatuhkan putusan mereka kepada masyarakat. ${ }^{8}$ Oleh karena itu, perlu untuk memahami presentasi keadilan sosial ketika menghukum pengguna narkotika. Presentasi keadilan sosial dalam menjatuhkan putusan kepada pengguna narkotika termasuk kesenjangan dalam literatur yang ada dan menjadi isu substansial, seperti yang ditunjukkan oleh karya Duff (2011). Setidaknya ada dua alasan utama mengapa penyajian keadilan sosial dalam putusan menjadi perhatian. Pertama, memahami latar belakang sosial orang-orang yang dihakimi dapat dianggap penting. ${ }^{9}$ Sebagai contoh, cara di mana para hakim berusaha untuk memahami

5 Duff, Anthony. "Responsibility, restoration, and retribution." Retributivism has a past: has it a future (2011), p. 63.

6 Hart, op.cit.

7 Tombs, Jacqueline. "A unique punishment: sentencing and the prison population in Scotland." (2004).

8 Duff, op.cit.

9 Hudson, Barbara. Justice in the risk society: Challenging and re-affirming justice in late modernity. (Sage, 2003). 
latar belakang sosial para pelanggar terkait narkotika dapat dianggap penting untuk interpretasi peradilan terkait keadilan. ${ }^{10}$ Studi ini menunjukkan bahwa upaya peradilan untuk mewujudkan keadilan sosial mendorong mereka untuk mempengaruhi proses peradilan. Kedua, putusan yang tidak proporsional telah dipertimbangkan oleh sejumlah penulis karena ini dapat membawa masalah seputar keadilan sosial. Studi sebelumnya telah mengindikasikan penolakan yudisial terhadap putusan dan diskriminasi yang tidak proporsional sebagai bentuk perlawanan. ${ }^{11}$ Perlawanan yudisial ini adalah bagian dari diskusi sejarah yang lebih luas tentang bentuk putusan yang akan mencapai keadilan sosial, yaitu distribusi kemanfaatan, penerimaan, dan kesempatan yang setara. ${ }^{12}$ Penelitian juga menunjukkan bahwa jika tidak ada perlawanan yang dilakukan oleh peradilan terhadap putusan yang tidak proporsional terhadap pelanggar terkait narkotika, negara-negara berkembang di Asia, termasuk Indonesia, kemungkinan besar mengalami masalah seputar keadilan sosial. ${ }^{13}$ Presentasi keadilan inilah yang masuk dalam pertimbangan yudisial ketika menjatuhkan putusan kepada pengguna narkotika di Indonesia yang akan penulis bahas lebih lanjut dalam makalah ini.

\section{Metode Penelitian}

Berdasarkan latar belakang permasalahan diatas maka metode penelitian terhadap persepsi para Hakim Indonesia dalam menjatuhkan hukuman terhadap pengguna narkotika menggunakan tipe penelitian campuran antara hukum normatif dan wawancara. Pendekatan kasus (putusan), dipilih sebagai metode pendekatan dalam pembahasan penelitian ini.

Dalam pendekatan kasus diperlukan untuk memahami alasan- alasan hukum (ratio decidendi) yang digunakan oleh hakim untuk sampai pada putusan pemidanaan. Dengan demikian penelitian ini merupakan upaya untuk menemukan hukum in concreto yang bertujuan untuk menemukan hukum yang sesuai dan yang akan diterapkan terutama berkaitan dengan penjatuhan hukuman terhadap pengguna narkotika.

Secara teknis pengumpulan data dilakukan dengan wawancara dengan para peserta aktif diantaranya, Hakim yang telah ditentukan sesuai dengan keperluan dan tujuan penelitian, berdasarkan pengalaman dalam menjatuhkan putusan perkara terkait pengguna narkotika. Berdasarkan tanggapan dan jawaban responden para hakim tersebut, maka dapat dianalisis hal hal sebagai berikut: faktor yang dapat mempengaruhi putusan hakim.

10 Nolan, J.L. Reinventing justice: The American drug court movement. (Princeton: NJ, 2003).

11 Nadelmann, Ethan A. "Criminologists and punitive drug prohibition: To serve or to challenge?." Criminology \& Public Policy 3, Vol. 3 (2004): 441-450.

12 Duff, op.cit.

13 Babor, T, Drug policy and the public good. (Oxford: Oxford University Press, 2010) 


\section{Pembahasan}

Pada bagian hasil ini, penulis membahas berbagai faktor yang menurut mayoritas peserta dapat berpengaruh pada putusan.

1. Pengaruh politik

Keinginan politis yang nyata untuk mengusung agenda perang melawan narkotika menciptakan ketegangan antara memenuhi agenda politik dan mengejar keadilan. Tampak jelas bahwa keprihatinan yudisial tentang pernyataan kepala Badan Nasional Anti Narkotika Republik Indonesia (BNN) baru-baru ini, ${ }^{14}$ yang menyatakan 'perang melawan narkotika', muncul sebagai tanggapan peradilan terhadap perang terhadap narkotika.

$\mathrm{Mr} \mathrm{X}$ [kepala BNN baru] menjawab: "buat pulau, dijaga oleh buaya, para pelanggar itu, yang ingin melompat, akan ditangkap oleh buaya di sana"... Namun, saya pikir itu tidak semudah itu! Jika orang dilepaskan hanya di sana [pulau] tanpa dukungan, yang akan membunuh orang, menyiksa orang, itu menambah permasalah lagi ... Memang, ini telah menjadi masalah nasional. (Hakim 30)

Seperti dapat dilihat dari pernyataan di atas, hakim peradilan yang ikut prihatin dengan suasana pernyataan politik yang mengusung agenda perang terhadap narkotika yang tampaknya memberikan tekanan pada hakim untuk menghukum pengguna narkotika. Suasana pernyataan politik ini dapat memberikan tekanan pada kebijaksanaan hakim yang berpartisipasi. Mengenai putusan minimum yang ditentukan oleh undang undang, Hakim 9 prihatin bahwa ini dapat mengakibatkan putusan penjara hingga lima tahun: “... Saya berbicara tentang keprihatinan saya; dakwaan berada di bawah Peraturan 111, dan $114^{15}{ }^{4}$ dan kami menghukum para pelaku putusan penjara lima tahun "(Hakim 9). Bersamaan dengan itu, Hakim 5 menyatakan, "Karena putusan minimum yang ditentukan oleh undang undang, saya menghukum pelaku empat tahun penjara" (Hakim 5). putusan penjara yang panjang mencerminkan pengaruh dari atmosfer pernyataan politik yang ada yang memberikan tekanan pada kebijaksanaan hakim yang berpartisipasi. Pengamatan saya mengungkapkan bahwa, meskipun lamanya putusan penjara tampaknya dikurangi dari tuntutan jaksa oleh para peserta, lamanya putusan penjara tetap lebih lama, kira-kira sekitar delapan tahun:

Majelis Hakim 4: Kami memutuskan bahwa ... [Majelis berdiskusi lagi untuk menyelesaikan lamanya putusan]: pelaku harus dihukum karena memiliki narkotika kelas satu, dan putusannya dikurangi dari sepuluh hingga delapan tahun

14 Penelitian ini dilakukan pada tahun 2015 pada saat terdapat pernyataan dari Kepala BNN terkait penempatan pelaku terkait narkotika di suatu pulau khusus.

15 Aturan 114 berkaitan dengan aturan tentang penjualan ilegal dan pembelian narkotika kelas 1 (misalnya ganja). Aturan ini berlaku minimal 5 tahun dan maksimal 20 tahun. 
penjara. Berat ganja, 728 gram, akan rampas oleh ${ }^{16} 5 \underline{2}$ [-[perampasan aset] negara. (Ekstrak dari sidang Catatan Pengamatan, Majelis Hakim 4)

Kutipan di atas adalah pengamatan persidangan yang menyoroti model putusan yang retributif yang dipengaruhi oleh suasana pernyataan politik perang melawan narkotika yang ada. Respon peradilan terhadap pengaruh politik non-populer menggemakan kekhawatiran peradilan.

... para pelanggar membutuhkan tempat berlindung; mereka tidak seharusnya dilepaskan sendirian ke dalam hutan. Mereka, juga, manusia, bukan harimau! Kita seharusnya tidak melakukan itu! Memang, ini telah menjadi ... masalah hukum yang harus kita tanggapi. Tidak mungkin kami menghukum semua orang. (Hakim 30)

Jelas dari kutipan di atas bahwa hakim peradilan yang berpartisipasi menganggap tidak mungkin untuk menghukum setiap pelaku narkotika atau melepaskan pelaku narkotika tanpa dukungan karena hal ini dapat melanggar hak-hak sipil dan masalah kemanusiaan. Ekstrak berikutnya menarik perhatian pada tantangan dalam menghukum mereka yang menggunakan narkotika ke penjara karena kelebihan kapasitas:

Jika kita menangkap pelaku penyalahgunaan narkotika ini berulang kali, ini akan menghasilkan kapasitas penjara yang penuh dengan orang-orang yang sakit dan tidak dengan orang-orang yang telah melakukan kejahatan. 'Melakukan kejahatan' adalah orang-orang yang menjual dan mendistribusikan narkotika dengan maksud melakukan kejahatan. (Hakim 6)

Tampaknya terdapat kebingungan di antara aparat hukum dalam sistem peradilan pidana (termasuk polisi, BNN, jaksa penuntut, dan hakim) mengenai apa yang seharusnya ditanggapi ketika merespons penggunaan narkotika. Sebagai contoh, Hakim 6 prihatin dengan tindakan tidak adil dalam menangkap, menuntut dan memenjarakan orang-orang yang dianggap oleh Hakim 6 tidak melakukan kejahatan (yaitu pengguna narkotika). Ketika pertama kali ditanya pertanyaan ini tentang pengaruh keinginan politik untuk menekan agenda perang melawan narkotika, Hakim 9 juga menganggap bahwa tidak ada manfaatnya dalam menjatuhkan putusan yang keras di bawah 'perang melawan narkotika' seperti yang dapat dilihat di bawah ini:

Apa aspek yang menguntungkan dari proses hukum? Tidak ada manfaat bagi negara, pelaku, dan masyarakat! Sejauh ini, kita masih bergantung pada retorika "perang melawan narkotika" tetapi apa manfaatnya? Saya cukup bingung

16 Perampasan aset obat sitaan ini tampaknya merupakan pertimbangan yang tidak biasa, biasanya obat sitaan akan dimusnahkan. 
tentang ini. Apakah kita secara sadar tahu apa yang kita lakukan sejauh ini? Mengapa narkotika begitu penting? Mengapa narkotika harus diatur secara khusus dan diperlakukan secara khusus; Saya tidak melihat manfaatnya! (Hakim 9)

Penjatuhan putusan yang keras di bawah rezim 'perang melawan narkotika' dipandang memiliki dampak negatif terhadap keadilan, sebagaimana dinyatakan oleh Hakim 18, “... Penahanan yang terlalu lama menyebabkan efek negatif, karena pelaku berbaur dengan para penyelundup narkotika dan pelaku kejahatan serius lainya ... "(Hakim 18). Ketika pertama kali ditanya tentang pengaruh politik tidak populer pada putusan, Hakim 18 menilai bahwa, setelah pengguna narkotika masuk penjara, kondisinya akan lebih parah. Di peradilan sampel, ketika mempertimbangkan efek negatif dari penjara, Hakim 5 menggambarkan bahwa para pelanggar mengalami kerugian dari putusan di bawah rezim 'perang melawan narkotika'. Hakim 5 menjelaskan bahwa ketika pelanggar yang memiliki masalah dengan penggunaan narkotika menghabiskan tujuh bulan di penjara, mereka akan mengalami pengalaman hampir mati: "Saya melihat bahwa bagi orang-orang dengan masalah penggunaan narkotika, putusan penjara tidak efektif karena, ketika saya melihat kondisi saudara saya selama enam sampai tujuh bulan di penjara, ia hampir saja mati "(Hakim 5).
Kerugian dari putusan di bawah rezim 'perang terhadap narkotika' dapat dilihat dari tiga kutipan berbeda yang disajikan di bawah ini: "Hakim 6 Panel: Juga, Majelis hakim berpendapat bahwa sanksi penjara akan berdampak negatif pada para pelanggar karena mereka adalah korban perdagangan narkotika. “ (Diekstraksi dari sidang Catatan Pengamatan, Majelis Hakim 19).

"Pemenjaraan pengguna narkotika akan memiliki efek negatif kepada pelaku di dalam penjara. Efek negatif ini adalah karena, di dalam penjara, para pelaku akan bertemu tahanan lain yang mengedarkan narkotika" (Hakim 6).

"Saya juga punya pengalaman pribadi terkait dengan keluarga saya ... Pada waktu itu, penjara di suatu wilayah tidak memiliki fasilitas perawatan dan memiliki over kapasitas yang berlebihan. Namun, saudara lelaki saya bertahan di sana selama tujuh bulan" (Hakim 5).

Dari kutipan yang disajikan dalam bagian ini, dapat disimpulkan bahwa pemenjaraan bagi pengguna narkotika dianggap sebagai merugikan. Beberapa melaporkan kerugian bagi pelaku, Negara dan masyarakat yang lebih luas untuk menghukum pengguna narkotika ke penjara. Sebagai contoh, Hakim 9 berkomentar, "Mengenai keadilan sosial, saya masih skeptis tentang manfaat proses investigasi dan putusan ... tidak ada 
manfaat bagi negara, bagi pelaku, dan bagi masyarakat" (Hakim 9). Mengenai ketidakefektifan putusan penjara bagi para pengguna narkotika, Hakim 24 menyatakan:

putusan belum tentu menyelesaikan permasalahan karena beberapa dari mereka ditangkap di penjara itu sendiri. Beberapa dari mereka menyelundupkan narkotika ke penjara, dan inilah yang terjadi di salah satu yurisdiksi. Beberapa dari mereka bergabung dengan sindikat narkotika di dalam penjara, dan entah bagaimana tidak ada efek jera. Beberapa dari mereka masih bisa mengendalikan pasar narkotika di dalam penjara ... Memang, menjatuhkan putusan terkait perkara narkotika itu agak menyulitkan. (Hakim 24)

Penjelasan Hakim 24 dan Hakim 9 menunjukkan kerugian yang ditimbulkan dari memenjarakan pengguna narkotika dalam konteks saat ini di peradilan Indonesia, yang merupakan saluran utama untuk memenuhi pernyataan politik perang terhadap narkotika.

2. Pengaruh Aparat Hukum

Cara polisi mengatur kasus dapat mempengaruhi interpretasi yudisial terhadap perkara pengguna narkotika. Ini sepertinya dapat dilihat pada penargetan polisi secara selektif kepada individu yang berasal dari latar belakang yang lebih miskin untuk dipolisikan. Dalam penelitian ini, sebagian besar peserta (yaitu 5 dari 31) prihatin dengan penargetan selektif. Penargetan selektif ini dirangkum oleh Hakim 27 yang mengungkapkan alasan berikut untuk keprihatinannya: 'Diperlukan kredibilitas selama proses investigasi, penuntutan, dan sidang peradilan; ini berarti bahwa penyelidikan polisi seharusnya tidak menargetkan secara selektif '(Hakim 27). Dari pernyataan mereka, Hakim 27 tampaknya prihatin bahwa kecenderungan polisi untuk selektif dalam mengungkap kasus narkotika menjadi permasalahan kredibilitas selama proses investigasi. Kelompok peserta lain, dari hakim peradilan, menyampaikan keprihatinan terkait kredibilitas aparat hukum pada sistem peradilan pidana, sebagaimana dikatakan Hakim 9:

Hal yang paling membuat saya prihatin di sini adalah bahwa yurisdiksi ini terlalu jelas dengan uang apakah kasus itu berisi uang atau tidak ... terlihat lucu bahwa dakwaan kasus mereka dipecah, dan semuanya didakwa berdasarkan Aturan 127. Satu pelaku dituntut untuk satu tahun penjara, dan dua pelanggar lainnya diadili selama empat hingga lima tahun penjara. Masalah kredibilitas ini adalah sesuatu yang menantang untuk diselesaikan ... tidak hanya pelakunya akan menjadi "sasaran empuk" tetapi, juga, kami, yang menerapkan UU Narkotika, akan menjadi "sasaran empuk". (Hakim 9) 
Kutipan di atas menyoroti keprihatinan hakim peradilan yang berpartisipasi bahwa pertanyaan tentang kredibilitas aparat hukum pada sistem peradilan pidana dapat mempengaruhi masalah-masalah seputar keadilan. Dalam situasi penargetan selektif ini, jumlah uang yang diterima dari pelaku seringkali mempengaruhi apakah pelaku akan dituntut, dituntut, dan dihukum dengan ringan atau berat. Pelaku yang berasal dari golongan ekonomi kelas bawah, yang tidak dapat menawarkan suap kepada petugas penegak hukum (yaitu polisi, BNN, jaksa penuntut), sering menemukan bahwa kasus mereka diubah dari penggunaan narkotika menjadi kepemilikan narkotika, yang dikenakan empat tahun 'pemenjaraan. Bahkan jika kasus mereka diatur untuk menggunakan narkotika, sering kali mereka tidak menerima asesmen dan kehilangan kesempatan untuk menerima pengobatan. Pengaturan selektif dari kasus ini terjadi karena penilaian dan perawatan sering ditawarkan kepada pelanggar yang dapat membayar. Dalam situasi ini, kekhawatiran hakim tentang kredibilitas seluruh proses pengaturan kasus narkotika dan mengatur dakwaan dan penuntutan dapat berdampak negatif terhadap putusan. Penargetan selektif ini menunjukkan bahwa keadilan yang kita lihat adalah kondisional - tergantung pada polisi yang mengatur kasus tersebut. Masalah penargetan selektif menyebabkan para peserta melakukan upaya ekstra di peradilan sampel untuk menafsirkan fakta-fakta hukumnya. Interpretasi yudisial ini jelas dalam cara para hakim yang berpartisipasi berusaha untuk mendefinisikan kembali siapa yang bisa menjadi saksi dalam kasus narkotika. Cara polisi bertindak sebagai saksi ditafsirkan oleh sebagian besar peserta sebagai kendala dalam menjatuhkan putusan. Penafsiran ini karena polisi sering membuat pernyataan yang kontradiktif. Pertimbangkan, misalnya, komentar Hakim 9:

... baik petugas kepolisian, yang menjadi saksi di peradilan, membuat pernyataan kontradiktif ... kesaksian kontradiktif itu membuat saya sadar bahwa dalam kasus narkotika ... peran polisi harus sebagai penyidik, bukan sebagai saksi ... itu ditemukan bahwa ada alibi ... Atas dasar itu, saya menyatakan tidak terbukti kasus didakwakan terhadap pelaku, dan peradilan banding dan kasasi menyetujui putusan saya ... (Hakim 9)

Cara pendekatan yang dilakukan oleh aparat penegakan hukum dalam kasus ini mempengaruhi pertimbangan hakim dalam menjatuhkan putusan rehabilitasi kepada para pengguna narkotika. Pengaruh ini karena, pada awal tahap investigasi, putusan untuk mengalihkan pengguna narkotika ke rehabilitasi berada di tangan polisi. Pertimbangkan, misalnya, harapan Hakim 30:

Tampaknya mungkin jika pengguna narkotika dialihkan di awal ... pengguna narkotika tidak akan 
lagi masuk peradilan ... Dari sudut pandang kami, akan lebih baik jika pengguna narkotika dapat direhabilitasi dan tidak dihukum ... karena mau tidak mau, itu membantu kita juga. (Hakim 30)

Kutipan di atas menyoroti harapan Hakim peradilan bahwa inisiatif pengalihan ke rehabilitasi harus dimulai dari bawah pada tahap investigasi. Dengan melakukan hal itu, kesediaan polisi untuk mengubah praktik mereka pada awal tahap investigasi akan berdampak pada rehabilitasi pengguna narkotika. Selain itu, wawancara dengan hakim peradilan yang berpartisipasi menunjukkan interpretasi fakta dan mereka tidak ragu untuk memutuskan pembebasan dengan sebagian besar kasus. Meskipun polisi dapat mengatur kasus ini, mereka bukanlah orang yang memutuskan putusan, dan oleh karena itu hasil putusan mungkin berbeda. Sebagaimana disampaikan Hakim 9, misalnya, menyebutkan:

... pelaku adalah ... bepergian ke pesta bersama pacarnya ... Ketika polisi menghentikan mereka, ditemukan kemudian bahwa benda di tangan wanita itu adalah ekstasi “. Kemudian, wanita itu diproses dan dibawa ke peradilan ... Saya pikir elemen "diberitahu tentang kepemilikan Ekstasi” tidak terbukti. Pelaku dipandang oleh hakim sebagai tidak memegang tanggung jawab pidana karena skala waktu yang sangat singkat dan itu terjadi dalam gelap, pelaku tidak sadar bahwa barang yang diserahkan kepadanya oleh pasangannya adalah ekstasi, oleh karena itu, pada saat itu, saya menjatuhkan putusan bebas atas kasus yang menimpa wanita itu ... peradilan banding dan kasasi juga menyetujui putusan saya. (Hakim 9)

Kutipan di atas menyoroti sebagian kecil dari peserta (yaitu 2 dari 17) yang membuat putusan bebas terhadap kasus terhadap wanita tersebut. Kewenangan pengalihan yang dimiliki oleh polisi memungkinkan mereka untuk mempertimbangkan keadaan wanita itu sehubungan dengan periode waktu yang singkat di mana dia diberikan obat-obatan di lingkungan yang sangat gelap. Mengingat kurangnya cahaya, wanita itu tidak menyadari bahwa barang yang diserahkan kepadanya oleh pasangannya adalah narkotika. Dari sudut pandang ini, polisi bisa saja memperingatkan wanita itu tanpa memproses lebih lanjut. Dalam keadaan ini, Hakim 9 (Urban) dengan hati-hati mempertimbangkan keadaan wanita itu dan memutuskan bahwa dia tidak bisa dihukum. Selain itu, wawancara dengan Hakim peradilan yang berpartisipasi menunjukkan bahwa hakim sendiri juga dapat menafsirkan fakta dari kasus tersebut. Sebagai Hakim 8, misalnya, menyebutkan:

Isi berkas perkara tidak mempengaruhi kami tetapi, sebagai referensi awal, untuk menyusun jenis putusan. Setelah membaca berkas 
perkara, kami akan memeriksa bukti bukti dipersidangan", bukti penggunaan narkotika setiap hari dan seterusnya dan kami akan membaca juga berita acara pemeriksaan saksi ahli. Ini akan menjadi referensi, tentang seperti apa kasus itu. Selain berita acara kesaksian, kami akan mengamati di persidangan. (Hakim 8)

Kutipan dari wawancara dengan Hakim 8 menyoroti interpretasi yudisial dari faktafakta kasus dengan mempertimbangkan berbagai perspektif (yaitu dari meninjau laporan yang berbeda, bukti dan observasi yudisial) sebelum tiba di putusan. Namun, interpretasi yudisial terhadap fakta-fakta kasus ini menjadi tantangan karena polisi sering kali tidak melampirkan hasil asesment tingkat penggunaan narkotika. Penilaian selektif ini menyebabkan sebagian kecil dari peserta (yaitu 6 dari 31) melakukan upaya ekstra di peradilan sampel untuk menetapkan fakta-fakta dari kasus ini, sebagaimana diungkapkan oleh Hakim 28:

Dalam praktiknya, hanya beberapa asesmen yang dilakukan. Sembilan dari sepuluh kasus narkotika tidak disertai dengan tes urin. Ketidakhadiran asesmen ini telah menimbulkan tantangan bagi hakim, khususnya, dalam membedakan antara korban dan pelaku ... hakim harus melakukan upaya ekstra di peradilan untuk menemukan fakta yang sebenarnya. (Hakim 28)

Kutipan di atas menyoroti Hakim 28 melakukan upaya ekstra di peradilan sampel untuk menetapkan fakta-fakta kasus dan untuk membedakan antara para pelanggar yang menjadi korban dari keadaan mereka dan pelaku yang sebenarnya. Respon peradilan terkait dengan topik ini tentang dampak dari keengganan polisi untuk memeriksa urin tahanan. Sebagai Hakim 31, misalnya, disebutkan:

Faktanya adalah bahwa kita perlu memeriksa apakah urin positif [untuk indikasi penggunaan obat]. Menurut pendapat saya, kita dapat mempertimbangkan pelaku tidak hanya ditangkap melalui penggunaan tetapi juga, setelah pelaku barubaru ini selesai menggunakannya. Biasanya, petugas kepolisian enggan memeriksa urin pelaku. Itu menjadi kenyataan dari kepolisian! (Hakim 31 , peradilan )

Kutipan di atas menyoroti keprihatinan Hakim 31 tentang tantangan untuk menetapkan fakta-fakta dari kasus tersebut karena fakta bahwa sebagian petugas polisi nampaknya belum dapat memfasilitasi pemeriksaan urin tahanan. Faktor lain yang menantang dalam mewujudkan keadilan tampaknya berasal dari presentasi pembuktian oleh jaksa. Sebagai contoh Hakim 7 dan Hakim 11, misalnya, menyampaikan: "Putusan kamisebagian besar bergantung pada dakwaan awal” (Hakim 7). 
“... pertama, jika kita menjatuhkan putusan di bawah standar minimum, jaksa pasti akan mengajukan banding atas putusan ..." (Hakim 11). Seperti yang diperlihatkan, kekhawatiran hakim peradilan yang berpartisipasi adalah bahwa putusan di bawah standar minimum seringkali mengakibatkan banding oleh jaksa penuntut. Ini sering menjadi tantangan karena hakim harus mengikuti putusan minimum standar untuk menghindari kasus yang diajukan banding. Dalam kutipan berikut, dua hakim peradilan menyatakan keprihatinan mereka tentang praktik diskriminatif dari jaksa penuntut:

Saya sangat kesal ketika ada kasuskasus di mana pelaku dapat dituntut berdasarkan Peraturan 127 karena jumlah obat yang lebih kecil, tetapi pelaku tidak dibebankan [oleh jaksa penuntut] di bawah Peraturan 127. Sebaliknya, ketika jumlah bukti dari penggunaan narkotika setiap hari lebih besar, pelaku dituntut [oleh jaksa penuntut] berdasarkan Aturan 127. (Hakim 23)

Kadang-kadang, kita tidak mengerti, pelaku sering didakwa [oleh jaksa penuntut] karena memiliki dan menyimpan narkotika; dan oleh karenanya kami menjatuhkan putusan minimum lima tahun. Biasanya pelanggar akan didakwa [oleh jaksa penuntut] untuk setidaknya tujuh tahun penjara.

\section{(Hakim 27)}

Kutipan di atas menyoroti sebagian kecil dari kekhawatiran peserta bahwa, untuk sejumlah kecil narkotika, jaksa cenderung menuntut berat terdakwa, sementara, untuk sejumlah besar narkotika, jaksa cenderung menuntut ringan terdakwa. Dalam kondisi seperti itu di mana batas pengertian antara 'memiliki dengan niat untuk menjual / menjual' dan 'menggunakan' menjadi kabur. Tidak jelas apakah kriteria tersebut didasarkan pada jumlah obat atau pada peran pelaku. Dalam situasi ini, penyajian bukti oleh jaksa penuntut umum sering kali menantang karena ditemukan setelah persidangan bahwa para terdakwa didakwa secara berbeda dari yang seharusnya. Akibatnya, praktik-praktik diskriminatif dari sebagian jaksa penuntut menambah tantangan untuk mewujudkan keadilan. Pengamatan saya di sidang peradilan mengungkapkan bahwa jaksa berkonsultasi dengan para peserta. Ini menunjukkan pengaruh jaksa pada putusan akhir dalam hal-hal tersebut.

Majelis Hakim 20: ... Kami istirahat sekarang! ...

[...] [Setelah sidang selesai, di dalam ruang sidang, jaksa berdiri dari kursinya dan berjalan dekatkebangku tempat Hakim 20 (Panel) duduk. Jaksa kemudian mulai berbicara dengan ketua majelis hakim, dan ketua majelis hakim mengangguk ketika dia mendengarkan apa yang 
dikatakan jaksa, dan kepala majelis hakim mulai berbicara kembali dengan jaksa, dan jaksa penuntut. Dia mengangguk dan kembali ke kursinya. Selanjutnya, Ketua Majelis hakim melihat ke kanan dan berbicara kepada anggota majelis hakim yang lebih muda. Ketua majelis hakim meminta konfirmasi tentang putusan akhir. Kemudian anggota majelis hakim yang lebih muda menganggukkan kepalanya, dan kemudian Ketua Majelis hakim melihat ke kiri dan berbicara kepada anggota majelis hakim yang lebih senior ketika dia meminta konfirmasi putusan akhir. Panel anggota yang lebih senior juga mengangguk, dan kemudian hakim melihat langsung ke para terdakwa, mengindikasikan bahwa putusan akhir telah dibuat dan sidang akan dilanjutkan] [...]

Majelis Hakim 20: Oke, sesi berlanjut [putusan didepan persidangan], kami memutuskan untuk mengurangi dari tuntutan dari lima hingga empat tahun dan itu adalah minimum. Bagaimana perasaanmu?

Terdakwa: [Menangis] (Ekstrak dari sidang Catatan Pengamatan, Majelis Hakim 20)

Seperti ditunjukkan di atas, Hakim 20 (Majelis) menskors sesi peradilan untuk memungkinkan jaksa berkonsultasi dengan para peserta. Jaksa memberikan masukannya tentang jangka waktu putusan penjara yang dapat diterima dalam kisaran standar putusan minimum. Di sini, pandangan jaksa penuntut tentang putusan akhir mengilustrasikan orkestrasi drama peradilan ini. Mengingatkan kembali sebagaimana disebutkan diatas tentang bagaimana hakim diberi tahu bahwa jaksa penuntut akan kemungkinan jaksa banding jika hakim menjatuhkan putusan di bawah standar minimum. Hakim 20 (Majelis) menanggapi masukan jaksa seolaholah dia akan berubah pikiran. Temuan ini menunjukkan bahwa bahkan pengenaan sanksi dipandang sebagai bagian dari negosiasi. Dengan kata lain, baik praktik diskriminatif jaksa penuntut dan pengenaan sanksi menambah tantangan bagi pengejaran keadilan. Jelas bahwa tanggapan peradilan terhadap topik ini tentang pengaruh dakwaan penuntutan menggemakan tantangan yang dijelaskan untuk mengejar keadilan:

Kami hampir tidak mengerti apa yang terjadi di balik dakwaan penuntutan ... jaksa penuntut mendakwa para pelaku secara berbeda dari faktafakta yang ditemukan di peradilan. Jaksa mendakwa pelaku berdasarkan ketentuan kepemilikan narkotika. Kemudian ketika di persidangan, pelaku tidak cocok dengan kriteria memiliki obat tetapi sesuai dengan kriteria menggunakan narkotika; namun, jaksa tidak mendakwa pelaku berdasarkan ketentuan penggunaan 
narkotika. Karena itu, ini adalah keputusan yang menantang bagi kami. Tidak mungkin bagi kita untuk mengikuti dakwaan penuntutan. (Hakim 30)

Temuan ini menunjukkan bahwa kontradiksi antara dakwaan yang diajukan dan bukti faktual dari penggunaan narkotika setiap hari yang diungkapkan di peradilan sampel telah meningkatkan tugas hakim dalam menjatuhkan putusan. Kutipan berikut menunjukkan bahwa salah seorang hakim merasa tertantang oleh prosedur banding ketika mereka dihadapkan pada resiko menjatuhkan putusan di bawah ketentuan standar minimum:

Saya menyadari bahwa, jika pelaku dijatuhi putusan di bawah minimum, itu tidak diragukan lagi akan diajukan banding. Juga, itu akan menyebabkan konsekuensi yang tidak terduga yang akan menyebabkan lebih banyak masalah bagi pelaku. Praktek-praktek ini telah menjadi kebiasaan. Hal ini sering terjadi. (Hakim 5)

Kutipan di atas menyoroti keprihatinan Hakim 5 tentang bagaimana potensi banding jaksa sering menjadi tantangan. Setelah kasus naik banding, peradilan Tinggi kemungkinan akan memperpanjang periode penahanan, yang mungkin memakan waktu sembilan puluh hari. Setelah dinyatakan bersalah, perpanjangan periode untuk penahanan diperhitungkan terhadap panjang putusan yang akan dijalani. Sebagai hasil dari perpanjangan penahanan ini, putusan pemenjaraan bagi pengguna narkotika di peradilan Tinggi kemungkinan akan lebih lama daripada putusan di peradilan negeri. Dengan demikian, nampaknya adanya prosedur banding memiliki dampak negatif terhadap keadilan. Namun, tidak semua hakim peserta memiliki persepsi yang sama. Sejumlah peserta tidak menganggap prosedur banding sebagai tantangan. Perhatikan, misalnya, komentar Hakim 6: "Setelah sidang di mana saya menjatuhkan putusan, jelas bahwa jaksa penuntut maupun pelaku tidak mengajukan banding. Oleh karena itu, tidak ada prosedur banding" (Hakim 6). Peserta lain malah menantang jaksa:

Kami menantang jaksa penuntut, juga, untuk mengajukan banding karena kami ingin mengetahui apakah putusan kami benar [apakah peradilan Tinggi menyetujui pertimbangannya tentang faktafakta kasus dan faktor-faktor tidak langsung yang mempengaruhi putusan] [...]. Jaksa tampaknya menerima putusan itu, dan pelaku juga senang dan menerima putusan yang lebih ringan. Karena itu, kasus menjadi final dan putusannya berkekuatan hukum mengikat. (Hakim 11)

Kutipan di atas menyoroti pengalaman Hakim 6 dan Hakim 11 tentang menantang jaksa ketika memutuskan putusan yang ringan. 
Sementara untuk mewujudkan keadilan masih membutuhkan interpretasi peradilan terhadap makna keadilan, ada harapan eksplisit dari sebagian kecil peserta agar para hakim berusaha untuk menerapkan tidak semata mata yang hukum yang tersurat hukum tetapi dasar moral yang tersirat dalam menjatuhkan putusan. Tampak jelas bahwa tanggapan peradilan terhadap topik ini tentang pengaruh hukum dan aparat penegakan hukum terhadap putusan kepada pengguna narkotika juga menggemakan pertimbangan hakim peradilan Tinggi tentang aspek tidak langsung ketika menjatuhkan putusan:

Kita harus mempertimbangkan tidak hanya kata-kata dari aturan tersebut tetapi juga konteksnya. Kita harus melihat tidak hanya apa yang tertulis di bawah hukum, tetapi juga semangat dibaliknya. Saya telah mempraktikkan kebijakan ini juga karena kasus narkotika paling dominan ... (Hakim 30)

Kutipan di atas menyoroti harapan hakim bahwa hakim peradilan Negeri mempertimbangkan esensi hukum dalam menjatuhkan putusan. Sebagai akibat dari ini, sebagian kecil dari peserta terlihat mempertimbangkan konteks bagaimana kasus-kasus tersebut diangkat ke persidangan, yang telah menjadi sumber pengetahuan mereka. Di peradilan sampel, sebagian kecil dari para peserta (yaitu 2 dari 17) juga mengakui ketegangan antara hakim dan resistensi jaksa karena sebagian kecil dari para peserta seringkali membebaskan terdakwa kasus narkotika. Ekstrak berikut menggambarkan hal ini:

Saya membebaskan terdakwa kasus narkotika. Putusan bebas ini adalah alasan Jaksa Penuntut Umum membenci saya, Kepala Kejaksaan setempat memperingatkan saya, juga, karena saya terlalu banyak membebaskan kasus terhadap para pelanggar ... (Hakim 9)

Kutipan di atas menyoroti ketegangan antara Hakim 9 dan jaksa penuntut mengenai putusan bebas bagi terdakwa kasus narkotika. Jaksa sering memprotes pembebasan terdakwa ini, dan putusan bebas ini cenderung dikuatkan oleh peradilan tingkat banding dan kasasi. Di peradilan sampel, sebagian kecil dari para peserta juga mengakui bahwa ketegangan antar lembaga penegak hukum menambah tantangan dalam mengejar keadilan. Beberapa hakim peradilan yang berpartisipasi (yaitu 2 dari 11) melaporkan ketegangan antar lembaga ini:

Terlepas dari hukum, tim asesmen dari berbagai multi-agensi harus dilibatkan dalam proses investigasi dan penuntutan ... Biasanya, file kasus ini disampaikan oleh jaksa penuntut tanpa asesmen kepada pelaku. Jika kasusnya tidak masuk akal, hakim harus melakukan upaya ekstra di peradilan untuk menemukan fakta. (Hakim 28) 
Di sini, Hakim 28 mengungkapkan ketegangan antar lembaga mengenai ketiadaan asesmen pendahuluan sebelum sidang, yang akan membuat masalah lebih menantang bagi sebagian kecil peserta terkait penafsiran atas fakta-fakta dan hukum yang relevan. Ketegangan antar lembaga ini menambah tantangan untuk mewujudkan keadilan. Selain itu, pengaruh Publik dan media juga menambah tantangan untuk mewujudkan keadilan.

3. Pengaruh Opini Publik dan Media

Faktor lain yang menyulitkan pengejaran keadilan tampaknya berasal dari opini publik dan penggambaran media terkait putusan untuk pelaku pengguna narkotika. Meskipun hakim tidak dipilih oleh masyarakat, sejumlah peserta (yaitu 9 dari 31) menjelaskan bahwa, kadang-kadang, mereka mempertimbangkan opini publik tentang putusan. Ekstrak berikut menggambarkan hal ini:

Jika putusannya adalah bahwa pelaku harus dihukum, maka opini publik tidak akan berpengaruh. Namun, jika putusannya tidak bersalah, maka opini publik dapat mempengaruhi ... Namun, opini publik bukanlah faktor acuan utama, itu hanya satu bahan, itu menjadi bumbu, dan menjadi bagian garam. (Hakim 9)

Kutipan di atas menyoroti pemahaman masyarakat bahwa orang yang dituduh tidak bersalah, dan inilah sebabnya mereka meminta hakim untuk membebaskan pelaku. Anggota- anggota masyarakat ini mengetahui tentang alibi dan mengerti bahwa orang itu tidak bersalah. Sebagian kecil dari para peserta menyadari bahwa masyarakat menginginkan pelaku untuk bebas dan menganggap bahwa ada alibi. Dalam situasi ini, hakim menerima opini publik ini, dan ini menyebabkan orang yang dituduh tidak dihukum. Oleh karena itu, dapat dianggap bahwa peran opini publik bertindak sebagai faktor "tambahan" yang berpengaruh pada putusan. Di peradilan sampel, sebagian kecil peserta (yaitu 2 dari 11) menunjukkan bahwa harapan publik didengar hakim dan hakim memastikan bahwa putusan memenuhi harapan masyarakat: "Jika kami percaya bahwa pelaku adalah murni pengguna narkotika, maka kami akan menjatuhkan putusan kepada mereka sebagai pengguna narkotika. Inilah yang diharapkan masyarakat, semoga putusan kami akan membantu "(Hakim 27). Seperti yang ditunjukkan, setelah ada keyakinan yudisial dalam rangka memenuhi harapan masyarakat, Hakim 27 akan berharap bahwa putusan mereka akan membantu pengguna narkotika. Oleh karena itu, harapan publik adalah sumber pengetahuan yang menambah nilai pada pertimbangan putusan. Namun pembenaran untuk bentuk pengetahuan dari publik ini perlu dipertimbangkan dengan hatihati. Di peradilan sampel, sejumlah peserta (yaitu 2 dari 17) menunjukkan cara mereka berhati-hati dalam menyaring opini publik:

Kita harus membedakan tingkat opini publik dan apakah itu opini 
jurnalis atau tidak. Oleh karena itu, jika jurnalis menulis tentang pendapat mereka sendiri, maka itu akan dianggap sebagai opini jurnalis yang dipublikasikan dan belum tentu opini publik. Sebaliknya, jika opini komunitas dilaporkan oleh jurnalis, itu akan dianggap sebagai opini publik. (Hakim 9)

Seperti yang diilustrasikan dalam kutipan di atas, solusi dalam menanggapi ekspektasi publik adalah dengan menyaringnya dan, dengan demikian, menanamkan dalam diri hakim nilai budaya dalam mempertimbangkan opini publik. Namun, tampaknya kedua tujuan tersebut memperjelas bahwa ekspektasi publik yang telah disaring dapat mempengaruhi putusan peradilan. Penempatan seperti itu kontras dengan pandangan hakim tentang menjadi otonom. Dalam membenarkan putusan mereka, sejumlah peserta menilai dampak dari menyaring opini publik ke dalam putusan mereka. Sebagai Hakim 14, misalnya, disebutkan: “... Kami menganggap jika kasus ini menarik perhatian publik, efek pada putusan .... (Hakim 14). Kutipan ini menggambarkan bahwa kasus yang menarik perhatian publik sering dianggap oleh jumlah peserta mengenai dampak putusan terhadap publik. Oleh karena itu, sejumlah peserta membenarkan putusan mereka berdasarkan harapan publik. Dalam sampel peradilan, terdapat variasi karena sejumlah peserta menunjukkan bahwa pembenaran putusan mereka adalah berdasarkan informan yang tidak mau disebutkan namanya ketika hakim bertemu orang-orang di komunitas tersebut. Sebagai Hakim 24, misalnya, disebutkan:

Kesaksian pelaku di peradilan tidak dapat menjadi referensi karena banyak pelaku mengatakan: "Saya hanya menggunakan narkotika sekali”, tetapi saya mendengar dari orang luar yang mengatakan: "mereka telah menjadi pemain narkotika profesional [terus berurusan dengan narkotika]". Saya mendengar desas-desus ini, juga, dari masyarakat, dari orang tak dikenal atau dari polisi yang menangkap mereka. (Hakim 24)

Kutipan di atas menyoroti peran negatif dari opini anonim dalam mengidentifikasi atribut stigmatisasi pelaku pengguna narkotika di peradilan. Identifikasi atribut stigmatisasi ini (yaitu 'pemain narkotika profesional' [terus-menerus berurusan dengan narkotika]) di masyarakat menambah tantangan untuk mewujudkan keadilan. Terdapat variasi yang sangat besar yang ada di antara para hakim yang berbeda di peradilan yang sama, sebagaimana dijelaskan oleh sebagian kecil dari para hakim yang berpartisipasi di peradilan sampel. Hakim 2 dan Hakim 7 melihat peran media dalam menjatuhkan putusan sebagai negatif karena media cenderung mendiskreditkan mereka. Hakim 3 menilai putusan penjara terkait dengan kecenderungan media untuk mengecam para hakim tersebut, terutama hakim progresif, yang menjatuhkan putusan 
di bawah standar minimum. Kecaman ini mencegah hakim mengirim pengguna untuk perawatan dan mendorong mereka untuk mengirim lebih banyak orang ke penjara: “... media melaporkan putusan kami secara tidak akurat, hanya setengah kebenaran" (Hakim 7).

Kami membaca artikel berita tentang kisah orang yang telah direhabilitasi, kemudian masuk kembali ke rehabilitasi, yang berarti bahwa, tidak ada peningkatan, tidak ada pertobatan, dan mereka tetap memiliki masalah dengan penggunaan narkotika. (Hakim 2)

... ketika jumlah metamfetamin adalah tiga kilogram. Satu pelaku adalah orang asing dan satu dari Indonesia. Saya merasakan tekanan luar yang ekstrem, terutama dari media pers dan wartawan ... berbanding terbalik, ketika kami menghukum pelaku dengan putusan seumur hidup, media menilai kami sebagai orang yang tidak dapat dipercaya dan tidak kompeten ... (Hakim 3)

Sejumlah peserta (yaitu 2 dari 17) menyebutkan bahwa media sering menggambarkan perilaku pelaku sebagai tidak berubah (yaitu pelaku terus memiliki masalah penggunaan narkotika). Sementara tujuan rehabilitasi yang sederhana dapat diukur dengan meningkatkan gaya hidup pelaku, sejumlah peserta tampaknya ditantang oleh harapan yang tidak realistis dari penyampaian berita oleh media tentang para pelaku yang terus memiliki masalah penggunaan narkotika. Selain itu, sejumlah peserta (yaitu 2 dari 17) prihatin bahwa masalah korupsi, yang tampaknya menembus aparat sistem peradilan pidana, adalah sumber ketidakpercayaan publik dan mengangkat masalah kredibilitas. Akibatnya, sejumlah peserta menghindari tuduhan yang dituduh publik. Sebagai Hakim 12, misalnya, disebutkan:

... kami khawatir bahwa kami berisiko tinggi diinterogasi oleh peradilan Tinggi: "Mengapa Anda melakukan pembebasan?" maka kita akan diperiksa: “Apa yang telah Anda terima?” Terkadang, kita tidak bisa menghentikan pandangan masyarakat tentang kita [hakim] [...]: "Apakah Anda [masyarakat] tidak pernah memiliki pemikiran positif tentang kami [hakim]!” ini adalah sesuatu yang tidak bisa kita hindari. Pandangan ini memengaruhi kita! (Hakim 12)

Secara keseluruhan, kutipan ini menggarisbawahi bahwa karena menjatuhkan putusan pembebasan sering dituduh oleh masyarakat sebagai pertanda korupsi untuk menguntungkan para pelaku. Hal ini membuat para hakim ini menghindari menarik tuduhan publik. Oleh karena itu, penghindaran ini telah berkontribusi terhadap penggunaan penjara yang lebih besar dan mengikuti tuntutan jaksa. Putusan penjara dibenarkan sebagai upaya peradilan untuk meminimalkan tuduhan publik. Dengan demikian, tuduhan publik 
menambah tantangan untuk mewujudkan keadilan.

Peserta Hakim dalam pertimbangannya juga mendasarkan pada faktor yuridis dan faktor sosiologis untuk pemidanaan. ${ }^{17}$ Dari pertimbangan faktor sosiologis, pemidanaan tindak pidana narkoba tidak terjadi dalam ruang hampa, tetapi sering dipengaruhi oleh struktur sosial. Dalam pembahasan ini, telah disajikan analisa bahwa pemidanaan rehabilitasi dipandang sebagai cara untuk menyelaraskan bentuk pemidanaan yang sesuai dengan harapan masyarakat.

\section{Simpulan}

Dari perspektif para hakim peserta dalam penelitian ini dan dari sudut pandang penulis sendiri, putusan kepada penyalahguna narkotika dianggap kompleks dan dipengaruhi oleh lima faktor utama (hukum, politik, publik, media, dan agama). Dalam hal pengaruh hukum, mayoritas hakim yang berpartisipasi cenderung menerima hukum tanpa pertimbangan. Sebagian kecil dari hakim yang berpartisipasi (yaitu 5 dari 31) cenderung menafsirkan hukum tanpa kebijaksanaan karena mereka tidak mengedepankan aspek moralitas. Sebagian kecil dari peserta juga merasa bahwa definisi hukum narkotika tentang penjualan dan penggunaan kabur. Batas definisi yang kabur ini menyebabkan sebagian besar peserta untuk menggunakan interpretasi mereka sendiri terhadap fakta dan hukum yang relevan. Dalam mempertimbangkan apakah tindakan menafsirkan hukum akan mencapai keadilan sosial yang lebihluas, sebagian tergantung pada pengaruh politik pada proses tersebut. Babor (2010) mencatat pengaruh hukum dan politik terhadap putusan narkotika. Politik yang tidak populer berpotensi menekan kriminalisasi penggunaan narkotika. Beberapa negara memperlakukan narkotika terutama sebagai masalah bagi penegak hukum dan pembuat kebijakan dan memberikan perhatian besar pada upaya-upaya untuk mengkriminalisasi penggunaan narkotika (termasuk di Amerika Serikat). Demikian pula, ini tampaknya menjadi kasus di Indonesia karena perspektif penegakan hukum mendominasi pembuatan kebijakan narkotika di Indonesia. Pengenaan sanksi dibuat kondisional tergantung pada kekuatan nilai-nilai yang mendukung kebijakan narkotika. Dan ini membuat penelitian ini signifikan dan sangat orisinal di bidang putusan peradilan pada umumnya dan khususnya dalam kaitannya dengan persepsi para hakim yang dipengaruhi oleh faktor yuridis dan faktor sosiologis dalam penjatuhan putusan kepada pengguna narkotika. 


\section{DAFTAR PUSTAKA}

\section{Jurnal}

Ashworth, A. Sentencing and criminal justice. Cambridge: Cambridge University Press. 2010

Ashworth, A. European sentencing traditions: accepting divergence or aiming for convergence? In: C. Tata and N.Hutton eds. Sentencing and society: international perspectives. Farnham: Ashgate Publishing, pp. 219-236. (2002)

Ashworth, A. Responsibilities, rights and restorative justice. British Journal of Criminology, 42(3), 578-595. (2002)

Babor, T. Drug policy and the public good. Oxford: Oxford University Press. (2010)

Duff, R.A. Punishment, communication, and community. Oxford: Oxford University Press). (2001)

Duff, R. A. Responsibility, restoration, and retribution. Retributivism has a past: has it a future, 63-85. (2011)

Feeley, M. M. The Process is the Punishment: Handling Cases in a Lower Criminal Court. Russell Sage Foundation. (1992)

Hart, H. L. A., Raz, J., Bulloch, P. A., and Green, L. The concept of law. $3^{\text {rd }}$. ed. Oxford: Oxford University Press. (2012)

Hudson, B. Justice in the risk society: challenging and re-affirming 'justice' in late modernity. London: Sage. (2003a)
Hudson, B. Understanding justice: an introduction to ideas, perspectives, and controversies in modern penal theory. Buckingham: Open University Press. (2003b)

Hutton, N. Sentencing as a social practice. In: S. Armstrong and L. McAra eds. Perspectives on punishment: the contours of control, Oxford: Oxford University Press, pp.155-174. (2006)

Mason, J. Qualitative research. London: Sage. (2007)

Nadelmann, E.A. Criminologists and punitive drug prohibition: to serve or to challenge? Criminology \& Public Policy, 3(3), pp.441-450. (2004)

Nolan, J.L. Reinventing justice: The American drug court movement. Princeton, NJ: Princeton University Press. (2003)

Reimann, M., \& Zimmermann, R. (Eds.). The Oxford handbook of comparative law. Oxford University Press. (2019).

Stevens, A., Berto, D., Frick, U., Hunt, N., Kerschl, V., McSweeney, T., Oeuvray, K., Puppo, I., Santa Maria, A., Schaaf, S., Trink1, B., Uchtenhagen, A., and Werdenich, W. The relationship between legal status, perceived pressure and motivation in treatment for drug dependence: results from a European study of Quasi-Compulsory Treatment. European Addiction Research, 12(4), pp.197-209. (2006) 
Tombs, J. [A unique punishment] Sentencing and the prison population in Scotland. Edinburgh: Scottish Consortium on Crime \& Criminal Justice. (2004) Available: http://www.scccj.org. uk/wp-content/uploads/2011/08/AUnique-Punishment.pdf [Accessed 25
February 2015] Research, Development and Statistics Directorate.

Ward, J. Punishing drug possession in the magistrates' courts: time for a rethink. European Journal on Criminal Policy and Research, 19(4), pp.289-307. (2013) 